\title{
EFEKTIVITAS PENGEMBANGAN POTENSI DIRI DAN ORIENTASI WIRAUSAHA DALAM MENINGKATKAN SIKAP WIRAUSAHA
}

\section{EFFECTIVENESS OF SELF DEVELOPMENT AND ENTREPRENEURIAL ORIENTATION IN IMPROVING ENTREPRENEURIAL ATTITUDE}

\author{
Anissa L. Kadiyono \\ Fakultas Psikologi Universitas Padjadjaran Bandung \\ Email: anissanugroho@gmail.com
}

\begin{abstract}
This study aims to determine the effectiveness Entrepreneurship Development Training to develop entrepreneurial potential students. Intervention program which achieves these goals is Entrepreneurship Development Training. This means, to enhance students' understanding of their potential and develop entrepreneurial orientation. Entrepreneurial scheme was developed by analyzing the attitudes towards entrepreneurship. The program design was tested in 147 vocational student in Jatinangor. Training is done through experiential learning methods. Training was conducted for 2 days with an emphasis on the ability to identify the activities and business opportunities in everyday life; identify self potential, motivation for achievement, creativity, and understanding leadership joints; and apply entrepreneurial attitudes and behavior in everyday life. Through analysis of Entrepreneurial Attitudes toward students, it is known that the Self Esteem owned by students classified as lower compared with other aspects that build an entrepreneurial attitude, namely Achievement, Innovation, and Personal Control. Needed encouragement and supervision of the environment in an effort to develop entrepreneurial potential possessed by the students.
\end{abstract}

Keyword: Entrepreneurial Potentiality Development, Entrepreneurial Attitude Orientation, Experiential Learning

\begin{abstract}
ABSTRAK
Penelitian ini bertujuan untuk mengetahui efektivitas rancangan program pelatihan pengembangan potensi kewirausaan terhadap kemampuan berwirausaha dapat dilakukan dengan melakukan intervensi pengembangan potensi kewirausahaan siswa. Rancangan program diuji coba pada 147 siswa SMK di Jatinangor. Pelatihan dilakukan melalui metode experiental learning. Pelatihan dilakukan selama 2 hari dengan penekanan pada kemampuan mengidentifikasi kegiatan dan peluang usaha dalam kehidupan seharihari, terutama yang terjadi di lingkungan masyarakat; mengenali potensi diri, motivasi untuk berprestasi, kreativitas, dan memahami sendi-sendi kepemimpinan; serta menerapkan sikap dan perilaku wirausaha dalam kehidupan sehari-hari. Melalui analisis Sikap terhadap Wirausaha siswa, maka diketahui bahwa kontribusiSelf Esteem yang dimiliki oleh siswa tergolong lebih rendah dibandingkan dengan aspek-aspek lain dalam membangun sikap kewirausahaan, yaitu Achievement, Innovation, dan Personal Control. Diperlukan dorongan dan pengawasan dari lingkungan sebagai upaya dalam mengembangkan potensi kewirausahaan yang dimiliki oleh siswa.
\end{abstract}

Kata Kunci : Pengembangan Potensi Kewirausahaan, Sikap terhadap Kewirausahaan, Pelatihan 
Kewirausahaan merupakan salah satu penopang pertumbuhan ekonomi di Indonesia. Perannya begitu sentral bagi kesejahteraan masyarakat Indonesia. Salah satu upaya pemerintah untuk menumbuhkembangkan jumlah pewirausaha, dilakukan sejak bangku sekolah. Penyempurnaan kurikulum pendidikan dengan dikeluarkannya Kurikulum 2013, yaitu dengan adanya Pendidikan Prakarya dan Kewirausahaan yang diwajibkan sebagai penerapan kurikulum baru tersebut di level setingkat SMA, membawa misi bahwa seyogyanya generasi muda Indonesia memiliki keterampilan dan mampu untuk mandiri dengan jiwa wirausaha.

Mata pelajaran kewirausahaan bukanlah hal yang baru bagi Sekolah Menengah Kejuruan (SMK). SMK didirikan sebagai lembaga pendidikan yang bertanggung jawab untuk menciptakan sumber daya manusia yang memiliki kemampuan, keterampilan, dan keahlian dalam bidang tertentu. Berdasarkan keahlian tersebut, lulusan diharapkan dapat menempati pekerjaan yang sesuai dengan bidang keahlian dan mampu menyesuaikan diri dengan lingkungan kerja. Namun, berdasarkan data Badan Pusat Statistik (2013), jumlah lulusan SMK yang berwirausaha hanya sekitar 3\% dari jumlah keseluruhan lulusannya. Sebagian besar (72\%) memutuskan untuk berkecimpung di dunia industri. Data ini tentu saja bukanlah data yang menggembirakan karena tidak sesuai dengan tujuan semula dalam mencetak wirausahawan muda.
Siswa SMK berada pada tahap perkembangan remaja. Salah satu tugas perkembangan remaja adalah menyiapkan karir dan masa depannya (Hurlock, 2002). Menurut teori perkembangan yang dikemukakan oleh Super dan Crites (1965), siswa SMK Kelas XII berada pada tahap eksplorasi periode kristalisasi. Pada masa ini remaja mulai mengidentifikasikan kesempatan dan tingkat pekerjaan yang sesuai serta mengimplementasikan pilihan karir dengan memilih pendidikan dan pelatihan yang sesuai, untuk akhirnya memilih pekerjaan yang sesuai dengan pilihannya. Pada tahap ini juga, individu berupaya untuk mencari kejelasan atau melakukan klarifikasi tentang apa yang ingin kerjakan. Belajar tentang peluang jenis pekerjaan dan belajar keterampilan yang diperlukan untuk masuk ke pekerjaan yang diminati. Selain itu, mereka mulai merealisasikan kemampuannya, minat-minat dan nilai yang dimilikinya termasuk salah satunya pada kegiatan berwirausaha.

Seyogyanya upaya pengembangan potensi kewirausahaan yang memang memiliki nilai besar bagi upaya perbaikan generasi di masa yang akan datang tidak hanya berupa mata pelajaran, namun menumbuhkan mental kewirausahaan pada siswa. Melalui motivasi otonom dalam mempelajari pengetahuan dasar, teknik, dan keterampilan dalam mengelola kemampuan wirausaha tersebut, maka wirausaha tidak hanya merupakan perilaku untuk kondisi masa kini namun menetap dalam diri individu sebagai modal dalam 
pengembangan kemampuan wirausaha individu tersebut kelak.

Havighurst (1972) mengemukakan bahwa dalam memilih pekerjaan, siswa perlu mengetahui dan memahami potensi yang dimiliki serta pengetahuan tentang dunia kerja yang akan mempengaruhi siswa dalam mengambil keputusan tersebut. Demikian juga dalam pengenalan wirausaha sebagai bidang karir yang dapat digeluti oleh siswa.

Diperlukan upaya eksternal untuk membantu siswa dapat lebih mengenali kemampuan dan kelebihan dirinya serta mengenalkan mental wirausaha agar siswa lebih siap untuk melakukan kegiatan wirausaha kelak. Oleh karenanya, peneliti menyusun program intervensi dalam upaya meningkatkan potensi kewirausahaan siswa. Intervensi yang dilakukan berupa pelatihan yang berisi simulasi kegiatan yang berkaitan dengan proses pengenalan diri dan orientasi wirausaha. Proses itu akan meliputi perlunya melakukan latihan yang memadai dalam mengenali diri, perlunya menetapkan tujuan yang akan diraih dan memilih strategi yang tepat untuk mencapainya, serta melakukan pertimbangan dan mempertahankan ketekunan dalam memecahkan persoalan dalam berwirausaha.

Respon siswa pada setiap tahap kegiatan akan diproses melalui aktivitas debrief. Tujuannya adalah untuk mendorong siswa menyebutkan penghayatan dari hasil perilakunya. Langkah penelitian yang dilakukan terdiri atas analisis kebu- tuhan, perancangan aktivitas pelatihan, pelaksanaan pelatihan, dan pengukuran hasil pelatihan. Berdasarkan uraian di atas, maka penelitian ini ingin mengetahui apakah program pelatihan pengenalan diri dan orientasi kewirausahaan dapat mengembangkan sikap terhadap kewirausahaan pada siswa SMK di Jatinangor Jawa Barat?

\section{METODE PENELITIAN}

\section{Desain Penelitian}

Penelitian ini merupakan bentuk applied research yang berupa implementasi program intervensi berupa pelatihan yang digolongkan sebagai experiental learning. Desain penelitian yang digunakan dalam penelitian ini berbentuk quasi experiment, yaitu suatu rancangan penelitian yang digunakan untuk melihat pengaruh dari pemberian suatu perlakuan (treatment) terhadap suatu permasalahan. Prosedur penelitian yang digunakan dalam penelitian ini adalah nonrandomized pretest-posttest control group design. Desain ini digunakan untuk melihat peranan pemberian program pelatihan pengembangan potensi kewirausahaan sebagai suatu perlakuan yang diberikan kepada kelompok penelitian. Kelompok eksperimen akan memperoleh perlakuan tersebut. Kelompok kontrol tidak memperoleh perlakuan. Penjelasan bagaimana penelitian ini berlangsung dengan menggunakan desain ini dapat dilihat pada desain sebagai berikut: 
Tabel 1. Rancangan penelitian

\begin{tabular}{lccc}
\hline \multicolumn{1}{c}{ Kelompok } & Prates & Perlakuan & Pascates \\
\hline Kelompok Eksperimen & O1 & $\mathrm{X}$ & O2 \\
Kelompok Kontrol & O1 & - & O2 \\
\hline
\end{tabular}

Keterangan :

O1 : Prates dilakukan pengukuran sikap terhadap kewirausahaan

$\mathrm{X}$ : Treatment, yaitu pelatihan pengembangan potensi kewirausahaan

O2 : Pascates, dilakukan kembali pengukuran sikap terhadap kewirausahaan pada subyek penelitian setelah diberikan treatment

\section{Subjek Penelitian}

Populasi penelitian ini adalah siswa SMK X di Jatinangor Jawa Barat dari semua jurusan, yaitu teknik otomotif, teknik kendaraan ringan, teknik sepeda motor, dan teknik jaringan komputer. Masing-masing jurusan terwakili sebagai subjek penelitian. Subjek dipilih dengan teknik cluster random sampling. terdiri atas dua kelompok. Kelompok eksperimen adalah siswa yang mendapatkan pelatihan sebanyak 147 orang, dan kelompok kontrol adalah siswa yang tidak mendapatkan pelatihan sebanyak 91 orang.

\section{Metode Pengumpulan Data}

Skala yang digunakan untuk pengumpulan data adalah skala sikap terhadap kewirausahaan. Sikap terhadap kewirausahaan meliputi achievement, personal control, innovation, dan self esteem (Robinson, Stimpson, Huefner, \& Hunt, 1991). Skala sikap yang telah diujicobakan kepada siswa SMK. Hasilnya 31 aitem lolos. Hasil analisis aitem menunjukkan koefisien realiabilitas skala, yaitu 0,967.

\section{Intervensi}

Berdasarkan studi pendahuluan mengenai intensi wirausaha yang disebarkan dalam rangka membuat rancangan intervensi, maka diperoleh hasil bahwa meski pelajaran kewirausahaan adalah pelajaran yang diwajibkan pada siswa SMK namun secara umum, sebagian besar peserta kurang memiliki semangat untuk menjalani wirausaha kelak. Motivasi untuk menggali potensi diri yang dapat menunjang kegiatan wirausaha juga rendah. Berdasarkan hal ini, peneliti bermaksud untuk membuat program pelatihan yang dapat meningkatkan motivasi mereka dalam menggali potensi diri dan mengembangkan intensi untuk berwirausaha.

Tujuan utama yang ingin dicapai dalam pelatihan ini meliputi proses pertama terjadinya regulasi teridentifikasi sebagai tahap awal munculnya motivasi otonom, yaitu conscious valuing of entrepreneurial activiy. Saat siswa menghayati bahwa setiap tahap dalam proses belajar itu penting untuk dilakukan, maka diharapkan proses kedua (self-endorsement of the goal) pun dapat tumbuh nantinya. Dengan demikian, tujuan utama aktivitas pelatihan ini adalah membuat siswa menyadari akan pentingnya menggali 
potensi diri dan mengembangkan intensi wirausaha.

Pencapaian tujuan berada pada level acceptance of a value dalam ranah afektif Bloom (Krathwohl, Bloom, \& Masia, 1964). Tahap ini merupakan tahapan awal dari penerimaan keberhargaan perilaku, fenomena, objek, dan lain sebagaimnya meskipun pada tahap ini individu belum terlalu yakin akan dapat mengambil nilai pentingnya wirausaha, tetapi mulai mempertimbangkan nilai tersebut.

Tujuan pelatihan ini dicapai melalui metode experiental learning. Tahapan experience learning yang dipilih peneliti dalam pelatihan ini adalah siklus belajar dari Pfeiffer dan Jones (1975) yang terdiri atas lima tahapan, yaitu mengalami (experiencing), menyatakan (publishing), memproses (processing), mengembangkan prinsip (generalizing), dan menerapkan (applying). Tahapan ini membantu peserta untuk menstrukturkan setiap pengalaman belajar dalam dirinya dan menemukan sendiri makna dari kegiatan belajar yang dilakukannya. Berikut ini adalah kerangka intervensi dalam upaya peningkatan potensi kewirausahaan sebagai berikut :

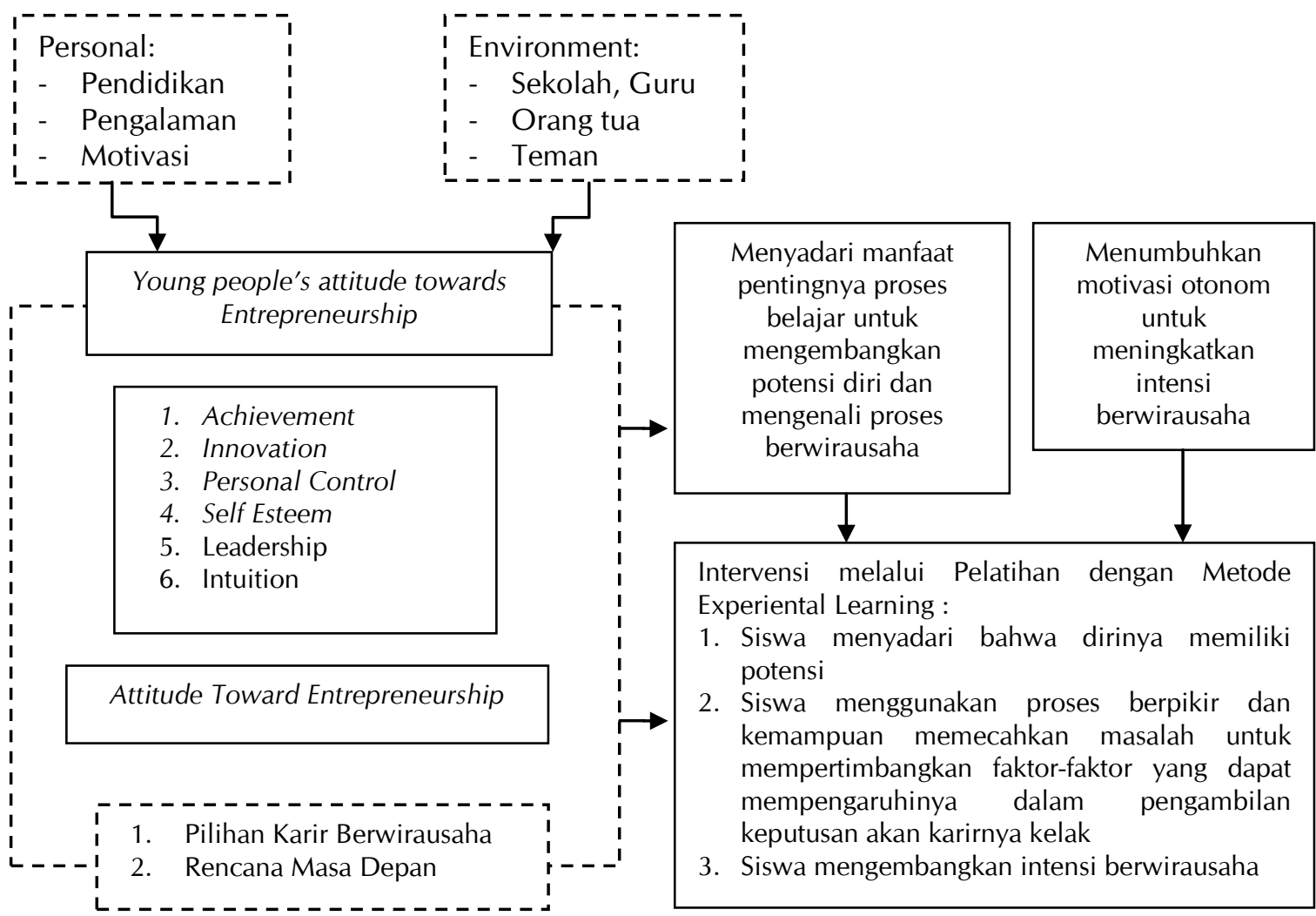

Gambar 1. Bagan Kerangka Intervensi 


\section{Metode Analisis Data}

Metode analisis yang digunakan adalah regresi dan Mann-Whitney. Teknik analisis regresi digunakan untuk mengetahui pengaruh empat hal pembentuk sikap terhadap wirausaha. Empat hal yang dimaksud adalah prestasi (achievement), inovasi (innovation), kontrol pribadi (personal control), dan harga diri (self esteem). Uji Mann-Whitney digunakan untuk menguji perbedaan antara sebelum dan sesudah perlakuan.

\section{HASIL PENELITIAN}

\section{Hasil Pelatihan}

Secara umum, peserta memiliki sikap terhadap kewirausahaan yang tergolong Tinggi $(72.00 \%)$. Sebagian kecil berada pada kategori sedang, yaitu sebesar $27.43 \%$.

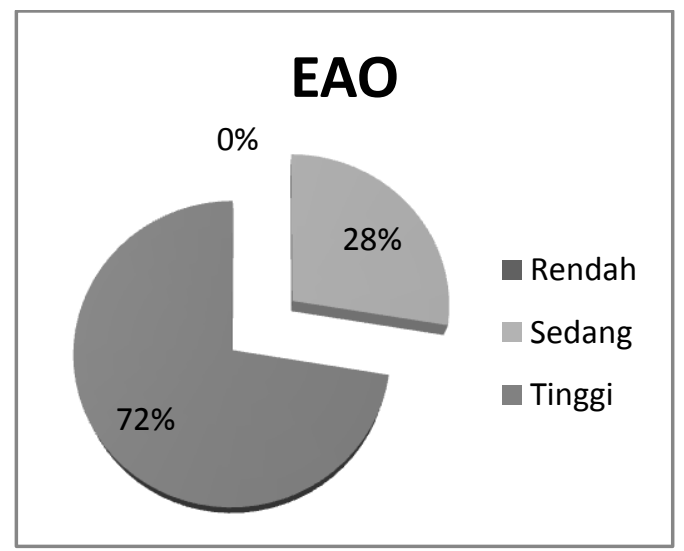

Gambar 2. Komposisi Entrepreneurial Attitude Orientation (EAO) siswa SMK
Hal ini menunjukkan bahwa siswa memiliki sikap yang positif terhadap entrepreneurship sebagai orientasi masa depannya saat ini yang dapat dibangun dari empat dimensi, yaitu achievement, personal control, innovation, dan self esteem. Bila dilihat dari dimensi pembangun orientasi wirausaha tersebut, maka hal ini dapat dilihat dalam gambar sebagai berikut :

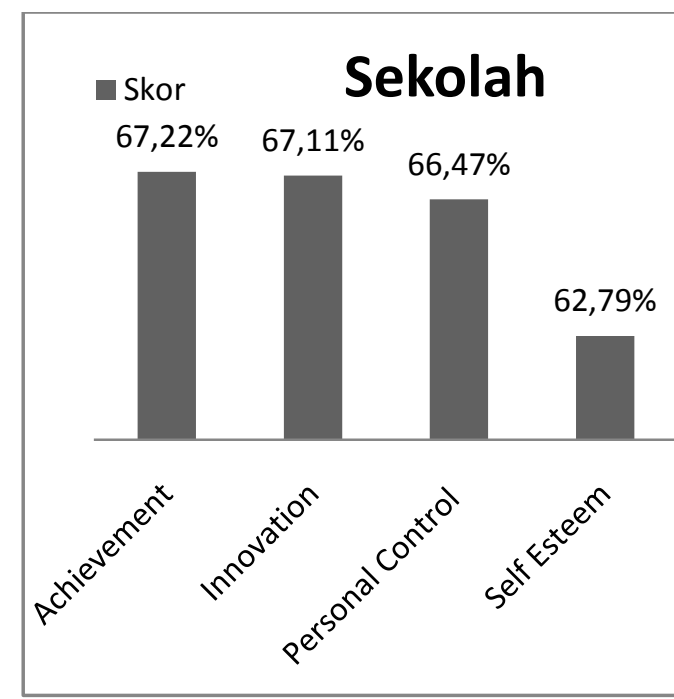

Gambar 3. Dimensi Pembentuk Entrepreneurial Attitude Orientation (EAO) siswa

Berdasarkan hasil analisis regresi, maka diperoleh hasil sebagai berikut : 


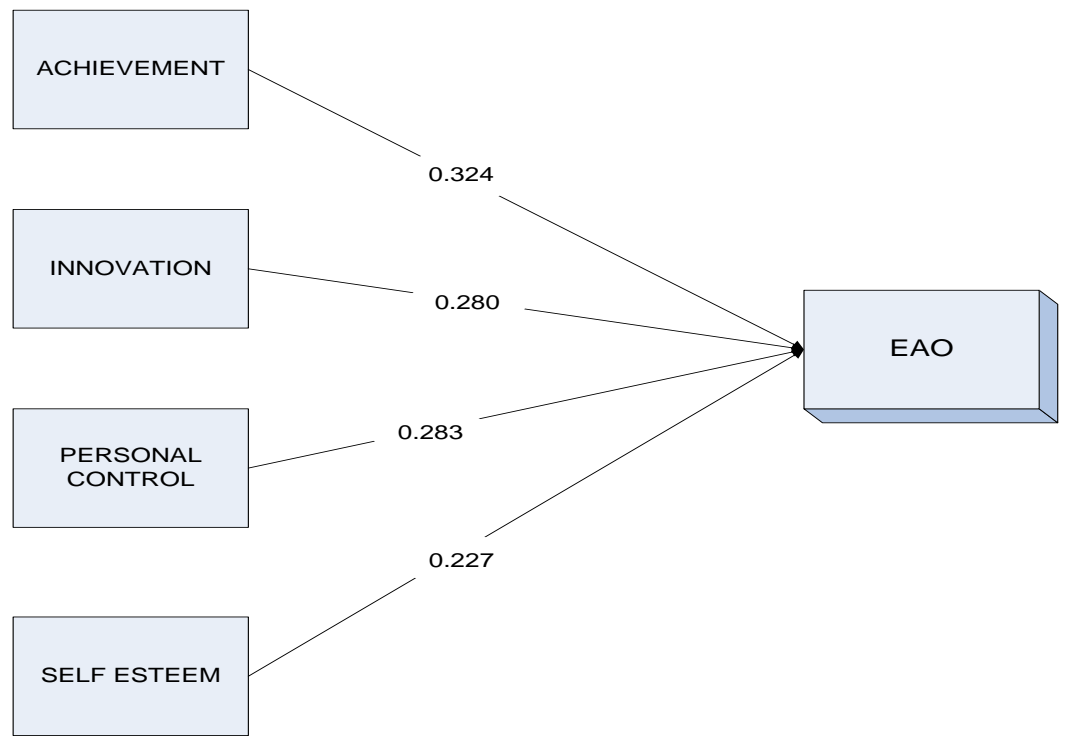

Gambar 4. Hasil Perhitungan Diagram Jalur EAO

Evaluasi Pelatihan

Evaluasi berdasarkan reaksi dalam penelitian ini adalah bagaimana peserta pelatihan dalam mengikuti program pelatihan dan bereaksi terhadap program tersebut. Hasilnya adalah sebagai berikut :

Tabel 2. Aspek Evaluatif Pelatihan

\begin{tabular}{llc}
\hline \multicolumn{1}{c}{ ASPEK EVALUATIF } & \multicolumn{1}{c}{ NILAI } & PERSENTASE \\
\hline Materi & Untuk mengetahui apakah materi pelatihan & 84.55\% \\
Pelatihan & bermanfaat bagi peserta & \\
Metode & Untuk mengetahui apakah metode yang digunakan \\
menstimulasi peserta & $84.09 \%$ \\
Fasilitator & $\begin{array}{l}\text { Untuk mendapatkan umpan balik mengenai proses } \\
\text { fasilitasi yang telah dilakukan oleh fasilitator }\end{array}$ & $82.75 \%$ \\
Waktu & $\begin{array}{l}\text { Untuk mengetahui apakah waktu yang digunakan } \\
\text { dalam pelatihan efisien }\end{array}$ & $80.30 \%$ \\
Sarana Pendukung & $\begin{array}{l}\text { Untuk mengetahui apakah sarana pendukung yang } \\
\text { digunakan dalam pelatihan memadai }\end{array}$ & $82.58 \%$ \\
Aktivitas & $\begin{array}{l}\text { Untuk mengetahui apakah aktivitas yang dilakukan } \\
\text { selama pelatihan menyenangkan }\end{array}$ & $85.50 \%$ \\
\hline
\end{tabular}

Dengan rata-rata penilaian sebesar kategori baik. $83.295 \%$ menunjukkan bahwa secara umum penilaian efektivitas pelatihan yang dirasakan oleh peserta berada dalam 
Efektivitas Program Pelatihan

Untuk mengetahui efektivitas pelatihan, maka disebar kuesioner untuk mengukur efektivitas pelatihan yang telah dilakukan. Hasilnya adalah sebagai berikut:

Tabel 3. Aspek Evaluatif Efektivitas Pelatihan

\begin{tabular}{clc}
\hline ASPEK EVALUATIF & \multicolumn{1}{c}{ NILAI } & PERSENTASE \\
\hline KEPUASAN & $\begin{array}{l}\text { Untuk mengetahui apakah tujuan dan sasaran pelatihan } \\
\text { tercapai }\end{array}$ & $82.92 \%$ \\
KEGUNAAN & $\begin{array}{l}\text { Untuk mengetahui apakah informasi yang disampaikan } \\
\text { dalam pelatihan ini berguna }\end{array}$ & $83.21 \%$ \\
& $\begin{array}{l}\text { Untuk mengetahui apakah pelatihan ini dapat } \\
\text { membangun potensi diri dan meningkatkan orientasi } \\
\text { kewirausahaan }\end{array}$ & $85.50 \%$ \\
\hline
\end{tabular}

Tabel di atas menunjukkan bahwa secara umum, sebagian besar peserta $(85,50 \%)$ merasa bahwa pelatihan yang diberikan bermanfaat dalam membangun potensi diri dan mampu meningkatkan intensi berwirausaha siswa. Pelatihan yang diberikan ini juga berguna $(83,21 \%)$ bagi orientasi masa depan mereka, serta peserta merasa puas $(82,92 \%)$ atas pelatihan yang telah diberikan.

\section{Hasil Uji Hipotesis}

Untuk menguji hipotesis diatas, dilakukan melalui hipótesis statistik berikut:

$\mathrm{H}_{0}: \varphi_{11}=0$ :

Tidak terdapat perbedaan yang signifikan pada sikap terhadap berwirausaha pada siswa yang mendapatkan pelatihan dan siswa yang tidak mendapatkan pelatihan Pengembangan Potensi Diri dan Orientasi Wirausaha
$\mathrm{H}_{0}: \varphi 11 \neq 0$ :

Terdapat perbedaan yang signifikan pada sikap terhadap berwirausaha pada siswa yang mendapatkan pelatihan dan siswa yang tidak mendapatkan pelatihan Pengembangan Potensi Diri dan Orientasi Wirausaha

Untuk mengukur hasil evaluasi pelatihan ini, maka dilakukan uji statistik non parametrik, yaitu uji Man-Whitney. Uji Man-Whitney digunakan untuk menguji hipotesis bahwa dua variabel yang merupakan dua sampel berkaitan mempunyai distribusi yang sama bila datanya ordinal. Kelompok 1 adalah siswa yang mendapatkan pelatihan sebanyak 147 orang, dan kelompok 2 adalah siswa yang tidak mendapatkan pelatihan sebanyak 91 orang. Berikut adalah hasilnya : 
Tabel 4.Data Statistik Uji Mann-Whitney

\begin{tabular}{cccc}
\hline UJI & P-values & Ho & \multicolumn{1}{c}{ Keterangan } \\
\hline $\begin{array}{l}\text { Mann- } \\
\text { Whitney }\end{array}$ & 0,03 & ditolak & $\begin{array}{l}\text { Terdapat perbedaan sikap terhadap kewira- } \\
\text { usahaan pada siswa yang mendapatkan pela- } \\
\text { tihan dan yang tidak mendapatkan pelatihan }\end{array}$ \\
\hline
\end{tabular}

Dengan p-value 0.037, yaitu $<0.05$, maka didapatkan hasil bahwa Ho ditolak. Hal ini berarti terdapat perbedaan signifikan antara siswa yang mendapatkan pelatihan dan yang tidak mendapatkan pelatihan Peningkatkan Potensi Diri dan Orientasi Wirausaha.

\section{PEMBAHASAN}

Hasil penelitian ini secara keseluruhan memberikan gambaran bahwa pada dasarnya siswa memiliki sikap yang positif terhadap wirausaha. Hal ini dapat dilihat bahwa skor rata-rata yang diperoleh siswa berada pada kategori tinggi $(72 \%)$. Sikap ini dipengaruhi oleh faktor personal dan lingkungan. Pada sisi personal, empat dimensi pembangun sikap terhadap wirausaha memiliki peranan mutlak dalam membentuk sikap tersebut. Dimensi pembangun sikap terhadap wirausaha yang terdiri atas achievement, innovation, personal control, dan self esteem secara bersama-sama membentuk sikap terhadap wirausaha (Robinson dkk, 1991). Bila dilihat secara parsial, maka diketahui bahwa aspek achievement merupakan faktor yang paling besar membentuk sikap terhadap wirausaha (0.324). Selain paling besar, jumlahnya juga lebih dominan dibandingkan dimensi lain (67.22\%) meski terpaut tipis dengan aspek innovation sebesar $67.11 \%$.

Berdasarkan analisis dimensi-dimensi pembangun Sikap terhadap Wirausaha, meski berada dalam kategori tinggi namun yang cukup memiliki perbedaan adalah derajat Self Esteem yang dimiliki oleh siswa yang cenderung lebih rendah daripada dimensi-dimensi pembangun Sikap terhadap Wirausaha lainnya. Rasa percaya diri ini adalah sumber dari rasa yakin terhadap kemampuan diri, kemampuan membangun optimisme, dan kemampuan untuk memacu diri untuk segera bangkit dari kegagalan. Hal ini juga yang menjadi fokus dari bahasan akan materi pelatihan Pengenalan Potensi Diri dan Orientasi Kewirausahaan yang menjadi intervensi dari asesmen yang dilakukan.

Tujuan pendidikan sekolah menengah kejuruan adalah meningkatkan kecerdasan, pengetahuan, kepribadian, akhlak mulia, serta keterampilan untuk hidup mandiri dan mengikuti pendidikan lebih lanjut sesuai dengan kejuruannya. Berdasar hal tersebut dapat diketahui bahwa lulusan SMK selain mengisi lowongan pekerjaan yang ada di dunia usaha dan 
industri, lulusan SMK juga mampu bekerja secara mandiri, dalam hal ini berwirausaha. Namun saat ini, pendidikan kejuruan masih sangat berorientasi pada penyiapan keahlian untuk mengisi kebutuhan tenaga kerja pada sektor formal, padahal lapangan kerja yang terbuka luas pada sektor informal memiliki potensi yang lebih besar untuk menyerap lulusan SMK. Mata pelajaran Kewirausahaan bertujuan agar peserta didik dapat mengaktualisasikan diri dalam perilaku wirausaha. Isi mata pelajaran Kewirausahaan difokuskan pada perilaku wirausaha sebagai fenomena empiris yang terjadi di lingkungan peserta didik. Berkaitan dengan hal tersebut, peserta didik dituntut lebih aktif untuk mempelajari peristiwaperistiwa ekonomi yang terjadi di lingkungannya. Pembelajaran kewirausahaan dapat menghasilkan perilaku wirausaha dan jiwa kepemim-pinan, yang sangat terkait dengan cara mengelola usaha untuk membekali peserta didik agar dapat berusaha secara mandiri. Akan tetapi, pada kenyataannya, matapelajaran kewirausahaan lebih banyak memberkan pengetahuan wirausaha bukan pada bagaimana menumbuhkan keingin-an dan kemampuan wirausaha siswa. Pada pelaksanaannya matapelajaran kewirausahaan lebih banyak teori dan melakukan prakarya bukan melakukan kewirausahaan itu sendiri. Pengujian statistik membuktikan bahwa tidak terdapat perbedaan dari jenis jurusan sekolah yang berbeda dengan sikap siswa terhadap wirausaha.
Pelatihan Pengembangan Potensi Diri dan Peningkatan Potensi Kewirausahaan dilakukan agar dapat menumbuhkan intensi siswa untuk berwirausaha, sehingga ketika lulus dari SMK siswa mau dan mampu untuk berwirausaha.

Berdasarkan hasil analisa deskriptif, maka diketahui bahwa Orientasi Wirausaha yang dimiliki oleh siswa berada dalam golongan Tinggi (4.61) dengan jumlah siswa yang memiliki Orientasi Wirausaha Tinggi adalah sebesar $72 \%$. Artinya siswa memiliki sikap yang positif terhadap wirausaha, baik dari segi kemungkinan pengembangan karir ke depan, kesempatan memperoleh pengetahuan baru, maupun kesempatan memperoleh pengalaman baru.

Sebagai remaja yang didorong oleh lingkungan eksternal dirinya, maka peran sekolah, guru, maupun pendidikan kewirausahaan yang didapat di sekolah adalah penting. Wirausaha mengacu pada orang yang melaksanakan proses penciptaan kesejahteraan dan nilai tambah. Jadi, jika para ingin menjadi wirausaha, maka siswa harus mempunyai sifat keberanian, keteladanan, dan berani mengambil risiko yang bersumber pada kemampuan sendiri. Wirausaha tidak semata-mata dimotivasi oleh financial incentive, tetapi oleh keinginan untuk melepaskan diri dari lingkungan yang tidak diinginkannya. Di samping itu wirausaha ingin menemukan arti baru bagi kehidupannya. Selain itu, untuk menjalankan kewirausahaan dan menjadi seorang wirausahawan diperlukan motivasi yang kuat dalam diri indi- 
vidu. Tidak semua orang memiliki motivasi yang sama untuk menjadi pengusaha. Sebagian orang menginginkan dirinya menjadi bos sendiri, ingin mencari uang dan kekayaan sebanyak-banyaknya, atau ada pula yang hanya ingin melakukan kegiatan yang biasa-biasa saja, namun sebagian lain cukup serius untuk mengikuti jejak orang-orang sukses, walaupun ada juga yang sekedar ikut-ikutan. Proses termotivasinya pun tidak semua orang sama. Ada yang karena faktor kebetulan, ajakan teman, memanfaatkan bakat, keterampilan, atau pendidikan yang diperolehnya, dan karena memahami apa yang dibutuhkan orang lain.

Kewirausahaan dapat pula didorong oleh seseorang yang menjalankan wirausaha, karena telah memberikan inspirasi dan minat untuk berwirausaha. Dorongan atau pemicu lainnya datang dari teman sepergaulan, lingkungan keluarga, sahabat, dan teman yang selalu yang mendiskusikan gagasan, atau karena adanya pengalaman bisnis kecil-kecilan yang berhasil sehingga termotivasi untuk membesarkannya. Hasil penelitian deskriptif, menunjukkan bahwa latar belakang keluarga yang juga memiliki profesi sebagai pewirausaha memiliki hubungan yang positif terhadap sikap siswa terhadap kewirausahaan. Siswa dengan keluarga yang berprofesi sebagai wirausahawan memiliki sikap positif yang lebih tinggi dibandingkan dengan siswa yang tidak memiliki orang tua yang berprofesi sebagai wirausahawan. Namun tidak demikian dengan pengaruh jurusan yang berbeda dalam SMK. Meski siswa terdiri dari jurusan Teknik Kendaraan Ringan, Teknik Sepeda Motor, dan Teknik Kom-puter dan Jaringan namun tidak terdapat perbedaan sikap terhadap kewirausahaan. Artinya seluruh jurusan sudah memiliki kesetaraan dalam menempatkan mata pelajaran kewirausahaan. Seluruh jurusan memiliki komposisi sikap terhadap kewirausahaan yang relatif sama. Selain itu, tidak ada pengaruh dari jenis kelamin yang berbeda ataupun usia yang berbeda dengan sikap terhadap wirausaha yang ditampilkan. Artinya, tidak ada pengertian bahwa laki-laki lebih memiliki sikap yang positif terhadap kewirausahaan ataupun yang lebih tua usianya memiliki sikap yang lebih positif. Kondisi lingkungan tempat profesi orangtualah yang lebih memberikan pengaruh terhadap sikap pada wirausaha. Dengan demikian, dapat dikatakan bahwa kewirausahaan bukanlah suatu hal yang dilahirkan, melainkan dibangun.

Siswa SMK memang memiliki potensi untuk menjadi seorang wirausahawan, namun pada kenyataannya, siswa SMK hanya dipersiapkan untuk menjadi karyawan di sektor industri, pariwisata, atau perkantoran. Pelatihan Pengembangan Potensi Diri dan Orientasi Kewirausahaan terbukti memiliki pengaruh terhadap sikap kewirausahaan siswa. Hasil pascates siswa memiliki skor yang lebih tinggi dibandingkan dengan hasil prates. Dengan z output sebesar -2.224 yang lebih besar daripada $z$ tabel, maka Ho ditolak. Hal ini memberikan kesim-pulan bahwa 
pelatihan memberikan efek yang nyata dalam meningkatkan pema-haman siswa terhadap potensi diri dan mengembangkan orientasi wirausahanya. Pelatihan terbukti menambah pengeta-huan, sikap dan keterampilan yang dijiwai oleh semangat wirausaha mandiri. Hal ini juga meningkatkan motivasi otonom untuk menambah pengetahuan dan menambah pengalaman untuk dapat terus belajar dan membuka orientasi masa depan siswa untuk dapat berwirausaha.

Pembuktian hipotesis dalam penelitian ini juga memberikan kesimpulan, bahwa terdapat perbedaan pada siswa yang mendapatkan pelatihan dan siswa yang tidak mendapatkan pelatihan Pengembangan Potensi Diri dan Orientasi Wirausaha pada siswa kelas XII SMK. Siswa yang mendapatkan pelatihan memiliki sikap yang lebih positif terhadap kewirausahaan dibandingkan dengan siswa yang tidak mendapatkan pelatihan. Namun sikap yang lebih positif saja belum cukup menjamin akan keberlangsungan niat siswa untuk berwirausaha. Hal yang perlu diwaspadai adalah Self Esteem yang cenderung tidak setinggi aspek lainnya, sehingga mudah goyah dalam mengambil keputusan dan kurang dapat menjaga rasa optimisme dalam diri. Dengan demikian, peran pendidikan kewirausahaan di sekolah memerlukan penekanan tidak hanya pada aspek keterampilan siswa dalam berkarya namun juga menekankan pada soft competency siswa dalam berwirausaha, terutama dari menjaga rasa percaya diri, kontrol diri, inovasi, maupun dorongan untuk terus berprestasi.

Sebagai pendorong, sekolah dan guru dapat memberikan contoh yang konkrit bagaimana melakukan wirausaha, bagaimana menumbuhkan motivasi dan kreatifitas berwirausaha siswa. Siswa juga perlu dirangsang untuk ditumbuhkan kreativitasnya, dengan memberinya ruang untuk bergerak tidak hanya sekedar mengikuti text book. Belum munculnya motivasi dalam diri siswa untuk melakukan wirausaha, hal ini dipengaruhi oleh belum adanya rangsangan untuk berwirausaha, menganggap bahwa berwirausaha tidak akan sukses, takut untuk rugi, ataupun kurang memiliki masa depan. Anggapan ini juga yang perlu untuk diperbaiki.

\section{SIMPULAN DAN SARAN}

\section{Simpulan}

Pertama: Siswa memiliki sikap positif terhadap wirausaha (entrepreneu-rial attitude orientation). Sikap terhadap wirausaha ini tergolong tinggi dan dimiliki oleh sebagian besar $(72 \%)$ siswa kelas XII SMK.

Kedua: Dimensi achievement memiliki sumbangan paling besar dalam membentuk sikap terhadap wirausaha $(0,324)$, diikuti oleh personal Control $(0,283)$, innovation $(0,280)$, lalu self esteem $(0,227)$.

Ketiga: Pelatihan Pengembangan Potensi Diri dan Orientasi Wirausaha berpengaruh pada Sikap terhadap Wira- 
usaha pada siswa Kelas XII SMK.Pelatihan memberikan efek yang nyata dalam meningkatkan pemahaman siswa terhadap potensi diri dan mengembangkan orientasi wirausahanya. Pelatihan yang dilakukan dapat menambah pengetahuan, sikap dan keterampilan yang dijiwai oleh semangat wirausaha mandiri.

Keempat: Terdapat perbedaan yang signifikan pada sikap terhadap berwirausaha pada siswa yang mendapatkan pelatihan maupun siswa yang tidak mendapatkan pelatihan Pengembangan Potensi Diri dan Orientasi Wirausaha. Siswa yang mendapatkan pelatihan memiliki sikap terhadap wirausaha yang lebih positif dibandingkan dengan siswa yang tidak mendapatkan pelatihan.

Keenam: Pelatihan yang diberikan memiliki rata-rata penilaian evaluasi sebesar $83.295 \%$ menunjukkan bahwa secara umum penilaian efektivitas pelatihan yang dirasakan oleh peserta berada dalam kategori baik. Materi pelatihan bermanfaat bagi peserta, dengan metode, fasilitator, waktu, sarana pendukung, dan aktivitas yang dilakukan memadai dalam menstimulasi siswa untuk meningkatkan pemahaman akan potensi diri dan mengembangkan orientasi kewirausahaannya.

\section{Saran}

Pertama: Peningkatan sikap terhadap wirausaha dapat dilakukan dengan menanamkan kebutuhan untuk berprestasi, melakukan inovasi, melakukan kontrol diri, dan memiliki rasa percaya diri dalam melakukannya.
Kedua: Kesempatan untuk melakukan praktik wirausaha diperlukan untuk mengasah softskill siswa. Pembentukan unit praktek kerja, seperti tempat pencucian motor untuk umum, bengkel, warung komputer, jasa service komputer dan kendaraan ringan, dan lain-lain diperlukan untuk menambah pengalaman siswa dalam mengasah softskill, seperti menumbuhkan rasa percaya diri, kebutuhan untuk berprestasi, serta berinovasi, sehingga siswa tidak hanya diberikan penekanan pendidikan pada aspek peningkatan keterampilan semata.

Ketiga: Upaya yang dapat dilakukan untuk menumbuhkan kemampuan wirausaha siswa dapat diberikan dengan memberikan pelatihan mengenai pengenalan potensi diri dan orientasi wirausaha, maupun mengundang motivator atau contoh sukses pengusaha muda yang merintis usaha wirausaha agar siswa memiliki wawasan baru dalam upaya berwirausaha.

\section{DAFTAR PUSTAKA}

Badan Pusat Statistik. (2013). Data Badan Pusat Statistik 2013. http://bps.go.id

Brown, D. (2002). Career Choice and Development Fourth Edition. San Francisco: John Wiley \& Sons, Inc.

Dit PSMK. (2006). Penyelenggaraan Sekolah Menengah Kejuruan Bertaraf Internasional. 
Kementrian Pendidikan dan Kebudayaan : http://referensi.data.kemdikbud.go.i d

Drucker, P.F. (1996). Konsep Kewirausahaan Era Globalisasi. Jakarta: Erlangga

Havighurst, J. (1972). The Developmental Tasks and Education.

Hurlock, E.B (2002). Psikologi Perkembangan. 5th edition. Erlanga: Jakarta.

Krathwohl, D.R., Bloom, B.S., \& Masia, B.B. (1964).Taxonomy of educational objectives: The classificationof educational goals. Handbook II: The affectivedomain. New York: David McKay.

Kirkpatrick, D.L. (2007). Evaluating Training Program : The Four Level. $3^{\text {rd }}$ edition. San Fransisco : BerrettKoehler Publishers, Inc

Meredith, G.G. (2000). KewirausahaanTeoridanPraktek.Seri Manajemen No. 97.PT. Jakarta: Pustaka Binaman Pessindo.
Pfeiffer, W. \& Jones, J. E. (1975). A Handbook of Structured Experiences for Human Relations Training. Vols. 1-5. La Jolla, CA : University Associates

Robinson, P.B., Stimpson, D.V., Huefner, J.C., \& Hunt, H.K. (1991). An attitude approach to the prediction of entrepreneurship. Entrepreneurship Theory \& Practice, Summer, 15(4), $13-30$.

Seagal, G.B. \& Schoenfeld, J. (2005). The Motivation To Become An Entrepreneur. International Journal of Entrepreneurial Behaviour \& Research, 11 (1), 00-000.

Silberman, M. (2003). 101 Active Learning. Jakarta : Salemba Empat

Super, D.E. \& Crites, J.O. (1965). Appraising Vocational Fitness By Means of Psychological Tests. USA : A Harper International Students.

Walter, G.A. \& Stephen, E.M. (1981). Experiental Learning and Change : Theory Design \& Practice. Toronto : John Wiley \& Sons. 